\title{
Smart city technologies as an innovative factor in the development of the sustainable cities
}

\author{
Irina A. Strelkova*, Vladislav V. Antropov, and Zhanna V. Ivanovckya \\ Financial University under the Government of the Russian Federation, Leningradsky prospect, 49, \\ 125167 Moscow, Russia
}

\begin{abstract}
The article deals with the problem of sustainability of modern cities in the context of the implementation of the concept of a "smart city", the combination of the technologies of which acts as an innovative factor in the development of modern urban infrastructure. The characteristics of the main elements of the "smart city", digital technologies used in its creation are given. The methodology and results of a comparative analysis of the urban digital infrastructure of the world's megacities in the context of COVID-19 are presented. The assessment of the global and Russian market of smart city technologies is given, trends and prospects of digital development of a modern city are identified as the most important factor in ensuring its sustainability. Recommendations are formulated for the development of solutions in the field of digitalization of urban space, taking into account the opinions of scientists and specialists in the field of management, socio-economic and humanitarian sciences. It is noted that efficiency and safety should become a priority in the implementation of smart city projects.
\end{abstract}

\section{Introduction}

\section{The concept of a "smart city", its main elements}

One of the ways to solve the problem of the sustainable cities development is the "smart city" concept. Changes are taking place at a tremendous speed in all spheres of society, associated with the widespread use of new digital technologies. "In the conditions of a slowdown in business activity, a decrease in trade flows between countries ..., an increase in imbalances in reproduction processes, the use of the possibilities of new forms .... of cooperation seems to be very important for business. In this case, we are talking about new information and communication technologies ..." [1, p. 421]

The situation in the global economy is such that "lawyers have to re-formulate the concepts of personal and private, states are faced with new problems in the field of equality and health care, sports organizations and educational institutions are changing the rating system, the pension fund and the labor market are adapting to the future ... dealing with a lot of difficult questions..."[2, p.494]

To a certain extent, this explains the absence of a generally accepted definition of a "smart city" - scientific research and the expert community have not yet developed a

\footnotetext{
*Corresponding author: i-strelkova@mail.ru
} 
common understanding of this term. The universal approach proceeds from the assumption that a smart city is the creation of various digital systems, with the help of which the tasks of the functioning and development of a metropolis are solved. There is another understanding of a "smart city" as a combination of technical, software, organizational and administrative solutions aimed at creating a comfortable urban environment: it includes engineering infrastructure, automation and dispatch systems, fire, road and industrial safety systems. The target function of these systems is the adaptive management of city resources, the operation of public services, traffic, parking, lighting, environmental monitoring, etc.

Within the framework of this direction, studies have appeared on the prospects and future intelligent technologies and their implications for social and environmental sustainability [3], certain and special factors have been identified that led to the transition from a simple "smart city" to "smart cities, focused on people [4] and other.

Today, there are various classifications of signs of a "smart city", with the differences depending on the states. In the European Union, the "smart city" is assessed according to 33 criteria. In addition, many global smart city rankings have been developed, which include various assessment criteria.

In one of the most famous ratings - Cities in Motion Index (CIMI), Moscow is ranked 86th among 174 megalopolises in the world. In the UN e-government ranking, it ranks 1st and 5th - according to Resonance Consultancy in the ranking of the best cities in the world. The Innovation Cities Global Index puts the Russian capital to 38th place, and the IMD smart cities rating - to 72 nd place. [5]

The Ministry of Construction of the Russian Federation has developed "Basic and additional requirements for smart cities ("Smart city" standard)", while the term itself is not unambiguously defined, but its main elements are indicated. These include as follows:

- service for involving citizens in solving urban development issues;

- "digital twin of the city" platform;

- "Smart" housing and communal services;

- digitalization of the urban environment, transport, public and environmental security systems.

It is assumed that the "smart city" will develop in 180 Russian cities with a population of 100 thousand people. The "IQ-index of cities" has been developed, in which Moscow at the beginning of 2020 ranked 1 st among cities with a population of more than 1 million people. According to experts, the leading role of Moscow is due to a well-prepared information infrastructure, financial security, high demand for unified and customized services (which is reflected in a significant share of services in the structure of the capital's GDP). An intelligent transport system, health services and remote services are actively developing. The Department of Information Technology (DIT) of the Moscow Government selects the technologies for implementation in the city, for testing which a separate division has been created - Smart City Lab.

\section{Materials and Methods}

\section{Smart city technologies.}

When creating a "smart city", innovative digital technologies are used that allow working with large amounts of data using tools such as Big Data, Data Science and Machine Learning. For example, Seoul has created a digital international R\&D platform for solving the urban problems - the Seoul Global Challenge - with the help of innovators' proposals. In 2019, at the Center for Infectious Diseases in Singapore, a system was implemented to track the movement of the employees, their contacts with each other. In the USA (Chicago), a building energy rating system has been developed. Since 2017, owners 
of the buildings (with an area of more than 4.5 thousand square meters) must regularly provide information to the city administration about energy consumption. Since 2019, buildings have been assigned an energy rating (on a scale of 1 to 4).

In 2019, Moscow launched "Collection and analysis of information from wearable devices" project at 21 construction sites. These devices track the movement of the workers oevr the construction site. This year this project will be expanded by another $25 \%$. As a result of digital control, it was possible to avoid violations of the terms of construction of urban facilities. Speech recognition technology is used to fill out documents in Moscow polyclinics in the departments of radiation diagnostics. 8 hospitals in Dagestan began to use the medical decision support system when prescribing treatment against the coronavirus. Computer vision technology has been launched in Tatarstan to monitor the compliance with the mask regime. Tsifra Group of Companies implemented a system for monitoring compliance with the sanitary standards at the enterprises. The Ministry of Telecom and Mass Communications introduces AI technology to collect the complaints of the citizens in the form of a single window service. The system for recognizing the passport data of passengers when selling the tickets operates in Russian Railways. [5]

The "smart city" is built on LPWA networks, which provide interaction over long distances between the computers, which is important - with minimal energy consumption. Various equipment is connected to them: gages, sensors, etc., which are used, in particular, in housing and utility services to automatically collect data from electricity meters and send them to a single system. According to the roadmap, in 2 years, LPWAN networks should cover $75 \%$ of large Russian cities, and by 2024 , almost all cities and $50 \%$ of rural settlements.

The 5G networks being introduced, despite the fact that they have high energy consumption and provide a shorter communication range than $4 \mathrm{G}$, will be used where a high data transfer rate is needed. For example, in telemedicine, for data exchange of selfdriving cars, etc. [6]

A significant trend in the development of smart city technologies is Big Data - the processing of large amounts of information necessary for making the effective decisions at all levels of the management system. IDC estimates that 41.6 billion devices will be connected to the IoT worldwide in 2025, generating 79.4 zettabytes of data. Big Data analysis, in particular, is very much in demand by the urban transport system, where it is necessary to calculate the route load and redistribution of passenger traffic, inform passengers about changes in traffic, etc. Cloud computing technology allows you to automate the collection of information from various engineering systems and equipment (sensors, meters, actuators, etc.), while reducing the cost of storing and processing data [7, p.7].

Citizens get access to the services of the "smart city" using the specialized digital platforms - aggregators of various services through which various services can be ordered. At the same time, one should not forget that there is "the trouble of the information age: the harmfulness of data is growing faster than the benefit obtained from them" [8, p.636]

\section{Results and Discussion}

\section{Assessment of the readiness of urban infrastructure in the context of COVID-19}

Starting from the idea that "... every extreme event should serve as a starting point ..." for scientific research $[8$, p.30] (in our case, a pandemic), it becomes necessary to assess the real state of affairs in the digitalization of the urban environment. The results of the analysis of the situation related to the operation of the city's infrastructure in the context of the spread of the coronavirus, which was carried out by the Higher School of Economics in the 15 largest metropolitan areas of the world, indicate that Moscow ranks 4th in terms of 
digitalization of the city's information infrastructure, sharing it with Turkish Istanbul. Lagging behind Singapore, Beijing and Shanghai, it is significantly ahead of London, Paris, Madrid, New York and other large cities in the world by this indicator (Fig. 1).

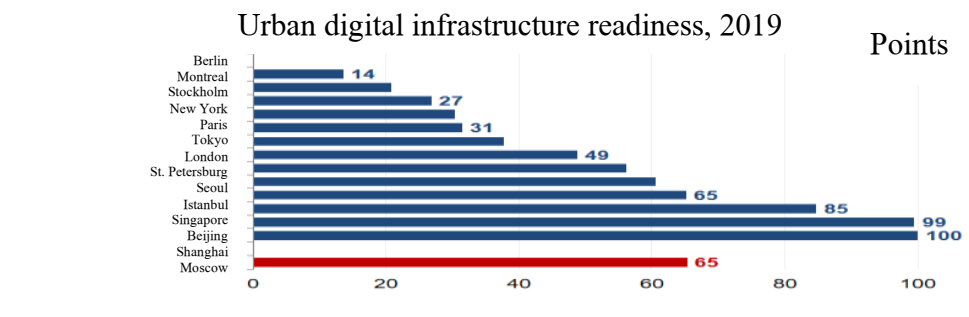

Source: IMD, SUTD, analysis of NRUHSE

Fig. 1. Digital Infrastructure Readiness (2019)

The methodology for calculating the indicator of the readiness of the urban digital infrastructure for work includes the determination of the performance index of all online systems $(25 \%)$, as well as private sub-indices, such as: the effectiveness of video monitoring systems $(25 \%)$; the operation of online registration systems in medical institutions (25\%); the functioning of the online system of public services $(25 \%)$. And based on the data obtained, the average value of all indicators was calculated.

In 2020 ranking of cities in the world, which also took into account the average speed of the Internet and the availability of online services in the context of the spread of coronavirus, Moscow took the 7th position - its aggregate figure was $45.5 \%$. The first line was still for Singapore (92.4\%), followed by Seoul (66.1\%) and Beijing (52.7\%). They are followed by Stockholm (50.4\%), Shanghai (50.3\%) and Tokyo (47.7\%). In this rating, Moscow outstripped such megacities as Paris (41.5\%, 8th line), Madrid (39.2\%, 9th position), New York (31.1\%, 12th place) and London (30.4\%, 13th place) (Fig. 2).

\begin{tabular}{|c|c|c|c|}
\hline & $\begin{array}{l}\text { Готовность иифровои } \\
\text { инфраструктуры }\end{array}$ & $\begin{array}{l}\text { Скорость } \\
\text { интернета }\end{array}$ & $\begin{array}{l}\text { Качество онлайн- } \\
\text { сервисов }\end{array}$ \\
\hline & $100 \%$ & $50 \%$ & $50 \%$ \\
\hline Москва & 45,5 & 25.8 & 65.3 \\
\hline Сингаnyp & 92,4 & 100,0 & 84.7 \\
\hline Cеул & 66,1 & 71,6 & 60,5 \\
\hline Пекин & 52,7 & 6.0 & 99.5 \\
\hline Стокгольм & 50,4 & 80,0 & 20,8 \\
\hline Шанхай & 50,3 & 0.5 & 100,0 \\
\hline Токио & 47.7 & 63,9 & 31,5 \\
\hline Париж & 41,5 & 52,6 & 30,4 \\
\hline Мадрид & 39,2 & 29,6 & 48,8 \\
\hline Санкт-Петербург & 34,8 & 13,6 & 56,1 \\
\hline Стамбул & 32,6 & 0,0 & 65,1 \\
\hline Нью-Йорк & 31.3 & 35.9 & 26,8 \\
\hline Лондон & 30,4 & 23,2 & 37,7 \\
\hline Монреаль & 17.9 & 22.3 & 13,6 \\
\hline Берлин & 5,8 & 11,6 & 0,0 \\
\hline
\end{tabular}

Fig. 2. Ranking of cities in terms of digital infrastructure readiness in the context of COVID-19 (2020)

Where: Москва - Moscow; Сингапур - Singapore; Сеул - Seoul;Пекин - Beijing; Стокгольм Stockholm;Шанхай - Shanghai;Токио - Тokyo;Париж - Paris;Мадрид - Madrid;Санкт-Петербург - St. Petersburg;Стамбул - Istanbul; Нью-Йорк - New York;Лондон - London;Монреаль Montreal;Берлин - Berlin; Готовность цифровой инфраструктуры - Digital infrastructure readiness; Скорость интернета - Internet speed; Качество онлайн сервисов - Quality of online services;Источник - Source; 
Practice has shown that in the difficult conditions of the high readiness mode, the availability of online services and the level of development of digital infrastructure turned out to be critically important factors in the successful operation of urban structures, emergency medical services, and security systems for businesses and the population. [9]

This was a consequence of the development and widespread use of Smart City technologies, as a result of intelligent solutions to create a sustainable urban environment, taking into account the interests of all subjects of the economic and public space.

\section{Market assessment of the technologies for the "smart city"}

Leading consulting companies estimate the volume of the world market in different ways. Thus, IDC analysts estimate that by 2023 global spending on digital solutions for creating the "smart cities" will amount to $\$ 189.5$ billion. At the same time, most of the investments will be for the development of smart meters and smart power grids. It is expected that positive growth dynamics will be observed in the sectors of intelligent transport systems, public safety, digital twins of the megacities.

Analysts at Grand View Research have estimated the volume of the global market for "smart cities" by 2025 at $\$ 237.6$ billion. At the same time, the average annual growth rate (CAGR) is estimated quite high - almost 19\%. The factors explaining this dynamics include an increase in the urban population, and, as a consequence, the need for rational use of limited resources. According to Mordor Intelligence company, the volume of the global market for the smart cities will grow from \$ 624.8 billion at the end of 2019 to $\$ 1.712$ trillion by 2025. CAGR growth over the period 2019-2025 18.3\% indicate the growth of urbanization and the development of the digital technologies.

According to the available estimates of iKS-Consulting, the volume of the Russian market of technologies for the "smart city" in 2018 exceeded 80 billion rubles (growth was $8 \%$ compared to 2017). At the same time, almost $93 \%$ of the market accounted for the digitalization of Moscow, another 5\% - for St. Petersburg and only 2\% - for other Russian cities, which indicates the unevenness of the regional digital development of the country. Overcoming such a significant gap will require not only time, but also a huge amount of investment in this area, solving the problem of providing qualified IT specialists, and creating a digital infrastructure. [5]

\section{Conclusion}

Trends and prospects for the development of smart city technologies

Experts point to the cooperation of teams and technologies as a trend in the development of smart city technologies: through absorption or merging into long-term partnerships. As an example, we can cite the activities of large Russian suppliers of innovative solutions, such as Sberbank (Sberbank ecosystem), Rostec, Rostelecom and Yandex. They are engaged in the absorption of promising start-ups, the organization of verticals within the company in various directions, the systematization and ordering of product lines, the creation of service ecosystems.

Many companies, as a rule, are not so large, but with strong teams they develop their business on their own, using modern cooperation opportunities based on digital platforms of the network professional community and development institutions.

Russian developers rely on the World Bank's experience in implementing smart city initiatives. Various projects of digitalization of urban infrastructure are presented today. Such, for example, as: Smart City technology as a tool for creating a comfortable urban environment by MTS, the Smart City project developed by the National Competence Center, Rostelecom's smart city technologies, technologies for using data analysis and AI in urban electronic services of DIT of Moscow, a model of a human-centered city of the 
Megafon company, etc. More than 500 smart city projects can be found in the showcase of world Smart City practices at ICT.Moscow [5].

Summarizing, we can state that today only a small part of the "smart city" concept has been implemented. "Moreover, having learned so many wonderful things, we have not figured out our goals ..." [2 P.501]. Harari IT specialists, as a rule, are engaged in the development and implementation of smart city projects, often without taking into account the theoretical and practical developments of economists, managers, engineers, psychologists, teachers, etc. "And any narrowing of the world around us can lead to explosive consequences, because it excludes some sources of uncertainty from the picture and forces us to misinterpret the fabric from which the world is woven" [ 8 p.54]. In the future, such digital technological and infrastructural solutions that prove the socioeconomic feasibility, efficiency and safety of the "smart city" in practice will be in demand by society and will ensure the sustainable development of the urban environment.

\section{References}

1. Vladislav Antropov, Vyacheslav Zubenko, Irina Strelkova, Petr Tolmachev, Revista Inclusiones, 7, 414 (2020)

2. Yuval Noah Harari, Sapiens, A Brief History of Humankind (2019)

3. Junyi Zhang, Shenjing He, Sustainable Cities and Society, www.elsevier.com/

4. N.A. Kolodii, N.A.Goncharova, V.S. Ivanova, Sociological journal 26(2), 102 (2020), /https://www.jour.fnisc.ru/

5. Competition in the digital avatar market, tax maneuver conditions in the IT industry and new ratings, https://ict.moscow/

6. Collapsed the network: the introduction of $5 \mathrm{G}$ next year was proposed to be postponed, https://iz.ru/

7. Commersant, 116, 7 (2020), https://www.kommersant.ru/

8. Nassim Nicholas Taleb, The black Swan, The Impact of the Highly Improbable (2019)

9. Application of data analysis and artificial intelligence in urban e-services, https://ict.moscow/ 